\title{
Effects of different doses of paclobutrazol and sucrose in the minimum in vitro growth of wild species of Manihot
}

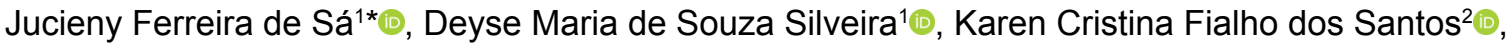

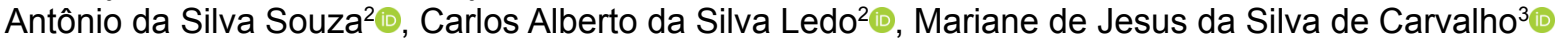 \\ ${ }^{1}$ Universidade Federal do Recôncavo da Bahia, Cruz da Almas, BA, Brasil. E-mail: jucienyferreira@hotmail.com; deyse_mss@hotmail.com \\ ${ }^{2}$ Embrapa Mandioca e Fruticultura, Cruz da Almas, BA, Brasil. E-mail: karen.santos@embrapa.br; antonio.silva-souza@embrapa.br; carlos.ledo@embrapa.br \\ ${ }^{3}$ Faculdade Maria Milza, Mangabeira, BA, Brasil. E-mail: marianejs@yahoo.com.br
}

ABSTRACT: In vitro conservation, under minimal growth conditions, allows prolonging the periods between subcultures without affecting plant viability, besides reducing the contamination risk and the space required for cultivation. Experiments were conducted by using $8 S$ as a basic culture medium, supplemented with combinations of five concentrations of paclobutrazol (PBZ - 0; 0.10; $0.20 ; 0.30$ and $0.40 \mathrm{mg} \mathrm{L}^{-1}$ ) and sucrose (SUC - $0 ; 5 ; 10 ; 15$; and $20 \mathrm{~g} \mathrm{~L}^{-1}$ ), resulting in 25 treatments, applied on three wild species: Manihot violaceae, M. flabellifolia and M. pseudoglaziovii. After 120 days of cultivation, the evaluated variables, namely plant height $(\mathrm{cm})$ and the numbers of mini-cuttings with $1 \mathrm{~cm}$, roots, shoots, green and senescent leaves, allowed verifying that, for the species M. pseudoglaziovii, the interaction of the $0.1 \mathrm{mg} \mathrm{L}^{-1} \mathrm{PBZ}$ and $5 \mathrm{~g} \mathrm{~L}^{-1} \mathrm{SUC}$ doses revealed a significant effect on the in vitro conservation. While for $M$. violacea, the combination of $10 \mathrm{~g} \mathrm{~L}^{-1} \mathrm{SUC}$ and $0.2 \mathrm{mg} \mathrm{L}^{-1} \mathrm{PBZ}$ is the most suitable for its conservation. Lastly, for M. flabelifolia, the concentrations used of SUC and PBZ did not prove efficient for in vitro conservation of the species.

Key words: germplasm preservation; Manihot flabellifolia; M. pseudoglaziovii; M. violaceae; sucrose

\section{Efeitos de diferentes doses de paclobutrazol e sacarose no crescimento mínimo in vitro de espécies silvestres de Manihot}

RESUMO: A conservação in vitro sob condições de crescimento mínimo permite prolongar os períodos entre os subcultivos sem afetar a viabilidade da planta, além de reduzir o risco de contaminação e o espaço necessário para cultivo. Experimentos foram realizados utilizando o $8 \mathrm{~S}$ como meio de cultura básico, suplementado com combinações de cinco concentrações de paclobutrazol (PBZ - 0; 0,10; 0,20; 0,30 e 0,40 $\mathrm{mg} \mathrm{L}^{-1}$ ) e sacarose (SAC - 0, 5, 10, 15 e $20 \mathrm{~g} \mathrm{~L}^{-1}$ ), resultando em 25 tratamentos, aplicados em três espécies silvestres: Manihot violaceae, M. flabellifolia e M. pseudoglaziovii. Após 120 dias de cultivo, as variáveis avaliadas, altura de planta $(\mathrm{cm})$, número de miniestacas com $1 \mathrm{~cm}$, número de raízes, número de brotações, número de folhas verdes e senescentes, permitiram verificar que a interação de $0,1 \mathrm{mg} \mathrm{L}^{-1} \mathrm{PBZ}$ e $5 \mathrm{~g} \mathrm{~L}^{-1} \mathrm{SAC}$ revelou efeito expressivo na conservação in vitro em $M$. pseudoglaziovii. Em M. violacea, a combinação de $0,2 \mathrm{mg} \mathrm{L}^{-1} \mathrm{PBZ}$ e $10 \mathrm{~g} \mathrm{~L}^{-1} \mathrm{SAC}$ é a mais indicada para sua conservação. As concentrações de PBZ e SAC avaliadas no presente estudo não se mostraram eficientes para conservação in vitro de M. flabelifolia.

Palavras-chave: preservação de germoplasma; Manihot flabellifolia; M. pseudoglaziovii; M. violaceae; sacarose

\footnotetext{
* Jucieny Ferreira de Sá - E-mail: jucienyferreira@hotmail.com (Corresponding author)

Associate Editor: Giuseppina Pace Pereira Lima
} 


\section{Introduction}

In vitro conservation under slow-growth conditions, by means of reducing cell metabolism, tissue growth and explants development, allows prolonging the periods between one subculture and another, without affecting their viability. This technique reduces the contamination risk and chances of a somaclonal variation appearing, allowing preservation of large collections in a reduced physical space. Growth retardation is usually achieved by varying chemical factors (composition of the culture medium), physical factors (changes in incubation conditions), or from the combination of both factors (Roca et al., 1991; Marco-Medina \& Casas, 2012).

Modifications in the culture medium may involve changes in concentration or the nature of growth regulators, reduction in the concentration of mineral elements, addition of osmotic compounds such as mannitol, sorbitol, and sucrose, and addition of growth retardants (Grattapaglia \& Machado, 1998). Sucrose is a frequently used osmotic agent, which acts in the culture medium by capturing, through osmotic gradient, the remaining intracellular water, allowing the growth to happen more slowly (Arrigoni-Blank et al., 2014).

For many plant species, growth inhibitors applied to the in vitro conservation medium are necessary to control growth and slow down the aging process. In this context, paclobutrazol consists of a plant growth regulator that acts by inhibiting the biosynthesis of gibberellin, perceptibly reducing both cell division and elongation, and consequently slowing down the plant growth without occurrence of cytotoxicity (Silva et al., 2003).

In the long term, techniques for cassava in vitro conservation are generally more economical and less risky when compared to field collections. They also have other advantages, such as reducing the space required for keeping these species, reducing losses due to climatic and soilinherent factors, the possibility of maintaining backup copies of the plants in field and ease of germplasm exchange. This is especially useful method for the wild Manihot species, which, unlike the cultivated ones, are notoriously difficult to keep in field collections outside their natural habitat and even in vitro.

However, in vitro germplasm conservation uses techniques that are fully manipulative and, in turn, adaptable to the particular conditions required for each species, justifying the need for specific studies that establish adequate conservation protocols. With this in mind, this study was conducted to evaluate the effects of different concentrations of paclobutrazol and sucrose on in vitro conservation, on three wild species under slow-growth conditions: Manihot violaceae (Pohl) Müll. Arg., Manihot flabellifolia Pohl and Manihot pseudoglaziovii Pax \& Hoff.

\section{Materials and Methods}

Experiments were conducted in the Laboratory of Tissue Culture (LCT) of the Nucleus of Advanced Biology (NBA) from Embrapa Cassava and Fruits, in Cruz das Almas, Bahia. Three wild cassava species were used in this study: Manihot violaceae (Pohl) Müll. Arg., M. flabellifolia Pohl and M. pseudoglaziovii Pax \& Hoff.

The basic culture medium used was $8 \mathrm{~S}$ (CIAT, 1984) plus concentrations of paclobutrazol (PBZ) $(0 ; 0.10 ; 0.20 ; 0.30$ and $0.40 \mathrm{mg} \mathrm{L}^{-1}$ ) and sucrose (SUC) $(0 ; 5 ; 10 ; 15$ and $20 \mathrm{~g}$ $\left.\mathrm{L}^{-1}\right)$, combined among themselves. Thus, the experimental design used was the entirely randomized, in a $5 \times 5$ factorial design, totaling 25 treatments, with 20 replicates/treatment, each one represented by a plant grown in a test tube. These 25 treatments with combination of studied factors (PBZ and sucrose), were applied on the three species under study ( $M$. violaceae, M. flabellifolia and $M$. pseudoglaziovii) and then isolated, resulting in three experiments.

Phytagel $^{\circledR}$ (2.4 $\left.\mathrm{g} \mathrm{L}^{-1}\right)$ was added as a gelling agent, after adjusting the $\mathrm{PH}$ of the culture medium to 5.8. After autoclaving for 20 minutes at $121^{\circ} \mathrm{C}$, the culture medium was distributed in $10 \mathrm{~mL}$-aliquots per glass test tube $(25 \mathrm{~mm}$ diameter and $150 \mathrm{~mm}$ long). Plants sectioned into nodal segments of approximately 1 $\mathrm{cm}$ containing one bud were used as the explants. Plants were then incubated in a conservation room, under environmental conditions that favor slow growth, that is, by using temperature of $22 \pm 1 \stackrel{\circ}{\circ}$, 12-hour photoperiod with light intensity of 18.5 $\mu \mathrm{mol} . \mathrm{m}^{-2} . \mathrm{s}^{-1}$, and $3 \mathrm{U}$ white-light fluorescent lamps.

The evaluation was performed at 120 days after inoculation of explants, by assessing plant height, number of 1-cm-minicuttings, number of roots, number of sprouts, and the number of green and senescent leaves. Data collected were subjected to the $\mathrm{F}$ test of the analysis of variance. Polynomial regression models were fitted to the means of paclobutrazol and sucrose. Statistical analyses were performed by employing the SISVAR statistical program (Ferreira, 2013). Means from the numbers of mini-cuttings, roots, sprouts, green leaves and senescent leaves were transformed into $\mathbf{V x}+0.5$, in order to meet the assumptions of the analysis of variance.

\section{Results and Discussion}

Using $8 \mathrm{~S}$ as the basic medium, different concentrations of paclobutrazol (PBZ), as a growth retardant, and sucrose (SUC), as a carbon source and osmotic regulator, were tested over three experiments, considering it is essential that the metabolism reduction is associated with maintaining plant viability for the efficiency of the in vitro conservation of germplasm,

In this perspective, two out six evaluated variables (plant height and number of senescent leaves) should present lower means correlated to higher values of the other variables (number of mini-cuttings, number of roots, number of shoots and number of green leaves), as a way to identify if the growth reduction does not hinder the multiplication, recovery and subsequent rescue of the plants.

Experiment I: Effect from different concentrations of paclobutrazol (PBZ) and sucrose (SUC) on in vitro conservation of the species M. pseudoglaziovii

From observing the analysis of variance, the interaction PBZ x SUC demonstrated a highly significant effect $(p<0.01)$ 
Table 1. Summary of the analysis of variance for plant height ( $\mathrm{PH}$, in $\mathrm{cm}$ ), number of mini-cuttings (NM), number of roots (NR), number of shoots (NS), number of green leaves (NGL) and number of senescent leaves (NSL) for M. pseudoglaziovii, as a function of the concentrations of paclobutrazol (PBZ) and sucrose (SAC).

\begin{tabular}{|c|c|c|c|c|c|c|c|}
\hline \multirow{2}{*}{ VF } & \multirow{2}{*}{ DoF } & \multicolumn{6}{|c|}{ MS } \\
\hline & & PH & NM & NR & NS & NGL & NSL \\
\hline PBZ & 4 & $139.58^{* *}$ & $2.43^{* *}$ & $0.29^{*}$ & $0.036^{\mathrm{ns}}$ & $0.42^{\mathrm{ns}}$ & $1.03^{* *}$ \\
\hline SUC & 4 & $1282.29^{* *}$ & $22.11^{* *}$ & $35.95^{* *}$ & $0.057^{* *}$ & $7.98^{* *}$ & $1.44^{* *}$ \\
\hline Error & 389 & 8.03 & 0.12 & 0.12 & 0.02 & 0.18 & 0.13 \\
\hline \multicolumn{2}{|c|}{ CV (\%) } & 30.90 & 14.15 & 18.30 & 10.54 & 16.24 & 36.96 \\
\hline
\end{tabular}

ns = non-significant; ${ }^{*}(p<0.05) ;{ }^{* *}(p<0.01)$.

on all evaluated variables for the species $M$. pseudoglaziovii (Table 1).

Coefficients of variation (CV \%) obtained in this study ranged from $10.54 \%$, for number of shoots (NS), to $36.96 \%$, for number of senescent leaves (NSL). Regarding the amplitude of the values from obtained coefficients of variation (CV\%), they may be associated with different biological responses of plants under in vitro experiments, deemed as normal for studies with plant tissue culture (Werner et al., 2012), hence ensuring a good experimental precision.

Table 2 illustrates the polynomial regression models, with the fittings of first and second degree models, with the coefficient of determination $\left(\mathrm{R}^{2}\right)$ ranging from $60.46 \%$ to $99.67 \%$ on the variable number of roots.

In this same context, Silva et al. (2019), when using PBZ on in vitro conservation of "catingueira" (Poincianella

Table 2. Regression equations, coefficients of determination, optimum doses and estimated values of plant height (cm), number of mini-cuttings, number of sprouts, number of green leaves and number of senescent leaves for Manihot pseudoglaziovii as a function of concentrations of paclobutrazol (PBZ) and sucrose (SUC).

\begin{tabular}{|c|c|c|c|c|c|}
\hline Interactions & Doses & Equations & $R^{2}(\%)$ & Optimal doses & Estimated values \\
\hline \multicolumn{6}{|c|}{ Plant height $(\mathrm{cm})$} \\
\hline PBZ (SAC) & 0 & $\hat{y}^{* *}=194.385 x^{2}-22.83 x+2.0198$ & 93.13 & 0.06 & 1.35 \\
\hline PBZ (SAC) & 5 & $\hat{y}^{* *}=-134.94 x^{2}+39.107 x+8.5023$ & 78.44 & 0.14 & 11.33 \\
\hline PBZ (SAC) & 15 & $\hat{y}^{* *}=-92.534 x^{2}+21.723 x+12577$ & 99.35 & 0.12 & 13.85 \\
\hline PBZ (SAC) & 20 & $\hat{y}^{* *}=-47.891 x^{2}+6.2169 x+14.1$ & 91.97 & 0.06 & 14.30 \\
\hline SAC (PBZ) & 0 & $\hat{y}^{* *}=-0.0449 x^{2}+1.4547 x+2.2396$ & 95.57 & 16.20 & 14.02 \\
\hline SAC (PBZ) & 0.1 & $\hat{y}^{* *}=-0.0387 x^{2}+1.405 x+1.7771$ & 99.11 & 18.15 & 14.52 \\
\hline SAC (PBZ) & 0.2 & $\hat{y}^{* *}=-0.0408 x^{2}+1.2907 x+2.6777$ & 81.44 & 15.82 & 12.88 \\
\hline SAC (PBZ) & 0.3 & $\hat{y}^{* *}=-0.04 x^{2}+1.218 x+3.3391$ & 84.42 & 15.23 & 12.61 \\
\hline \multicolumn{6}{|c|}{ Number of mini-cuttings } \\
\hline PBZ (SAC) & 0 & $\hat{y}^{*}=48.004 x^{2}-11.263 x+1.5455$ & 95.88 & 0.12 & 8.80 \\
\hline PBZ (SAC) & 5 & $\hat{y}^{* *}=-90.284 x^{2}+25.474 x+6.0208$ & 86.11 & 0.14 & 7.82 \\
\hline PBZ (SAC) & 10 & $\hat{y}^{* *}=-4.1315 x+7.764$ & 72.86 & 0 & 7.76 \\
\hline PBZ (SAC) & 15 & $\hat{y}^{* *}=-51.698 x^{2}+11.7 x+7.5095$ & 94.78 & 0.11 & 8.17 \\
\hline PBZ (SAC) & 20 & $\hat{\mathrm{Y}}^{* *}=-7.5245 \mathrm{x}+8.7853$ & 87.88 & 0 & 8.78 \\
\hline SAC (PBZ) & 0 & $\hat{y}^{* *}=-0.0308 x^{2}+0.9071 x+1.8354$ & 91.31 & 14.73 & 8.51 \\
\hline SAC (PBZ) & 0.1 & $\hat{y}^{* *}=-0.0294 x^{2}+0.9109 x+1.8017$ & 93.05 & 15.49 & 8.86 \\
\hline SAC (PBZ) & 0.2 & $\hat{y}^{* *}=-0.028 x^{2}+0.837 x+1.8732$ & 85.07 & 14.95 & 8.13 \\
\hline SAC (PBZ) & 0.3 & $\hat{y}^{* *}=-0.0266 x^{2}+0.6806 x+2.7745$ & 70.98 & 12.79 & 7.13 \\
\hline \multicolumn{6}{|c|}{ Number of roots } \\
\hline PBZ (SAC) & 0 & $\hat{y}^{+*}=47.959 x^{2}-12.469 x+0.2878$ & 85.71 & 0.13 & 0.52 \\
\hline PBZ (SAC) & 5 & $\hat{y}^{* *}=-66.122 x^{2}+22.331 x+2.3201$ & 61.10 & 0.17 & 4.21 \\
\hline PBZ (SAC) & 10 & $\hat{y}^{* *}=41.801 x^{2}-10.927 x+4.0022$ & 72.49 & 0.13 & 3.29 \\
\hline PBZ (SAC) & 15 & $\hat{y}^{* *}=-48.113 x^{2}+16.52 x+5.0007$ & 97.75 & 0.17 & 6.49 \\
\hline PBZ (SAC) & 20 & $\hat{\mathrm{y}}^{* *}=-35.021 \mathrm{x}^{2}+8.7863 \mathrm{x}+6.3687$ & 60.46 & 0.13 & 6.92 \\
\hline SAC (PBZ) & 0 & $\hat{y}^{* *}=-0.0122 x^{2}+0.5164 x+0.2269$ & 97.67 & 21.16 & 5.69 \\
\hline SAC (PBZ) & 0.1 & $\hat{y}^{* *}=-0.0007 x^{2}+0.4086 x+0.0915$ & 99.67 & 29.19 & 6.05 \\
\hline SAC (PBZ) & 0.2 & $\hat{y}^{* *}=-0.0059 x^{2}+0.4241 x+0.5804$ & 77.10 & 35.94 & 8.20 \\
\hline SAC (PBZ) & 0.3 & $\hat{y}^{* *}=-0.0323 x^{2}+0.8674 x+0.2366$ & 97.47 & 13.43 & 6.06 \\
\hline \multicolumn{6}{|c|}{ Number of sprouts } \\
\hline PBZ (SAC) & 5 & $\hat{y}^{* *}=-7.449 x^{2}+2.5224 x+1.131$ & 62.55 & 0.17 & 1.34 \\
\hline PBZ (SAC) & 20 & $\hat{y}^{* *}=7.0502 x^{2}-2.8531 x+1.3745$ & 94.35 & 0.20 & 1.09 \\
\hline SAC (PBZ) & 0 & $\hat{y}^{* *}=0.0136 x+1.0494$ & 83.20 & 20.00 & 1.32 \\
\hline SAC (PBZ) & 0.4 & $\hat{y}^{* *}=0.0159 x+0.9964$ & 78.33 & 20.00 & 1.31 \\
\hline
\end{tabular}

Continues on the next page 
Continuation of Table 2

\begin{tabular}{|c|c|c|c|c|c|}
\hline Interactions & Doses & Equations & $\mathbf{R}^{2}(\%)$ & Optimal doses & Estimated values \\
\hline \multicolumn{6}{|c|}{ Number of green leaves } \\
\hline PBZ (SAC) & 0 & $\hat{\mathrm{V}}^{* *}=43.844 \mathrm{x}^{2}-10.699 \mathrm{x}+3.8231$ & 93.67 & 0.12 & 3.17 \\
\hline PBZ (SAC) & 5 & $\hat{y}^{* *}=-62.971 x^{2}+16.512 x+7.389$ & 84.69 & 0.13 & 8.47 \\
\hline PBZ (SAC) & 20 & $\hat{\mathrm{y}}^{* *}=-4.9165 \mathrm{x}+7.9922$ & 84.23 & 0 & 7.99 \\
\hline SAC (PBZ) & 0 & $\hat{y}^{* *}=-0.0294 x^{2}+0.7644 x+3.9391$ & 96.81 & 13.00 & 8.91 \\
\hline SAC (PBZ) & 0.1 & $\hat{y}^{* *}=-0.0258 x^{2}+0.6866 x+4.0239$ & 75.85 & 13.31 & 8.59 \\
\hline SAC (PBZ) & 0.3 & $\hat{y}^{* *}=-0.0259 x^{2}+0.5804 x+4.509$ & 74.68 & 11.20 & 7.76 \\
\hline \multicolumn{6}{|c|}{ Number of senescent leaves } \\
\hline PBZ (SAC) & 0 & $\hat{\mathrm{V}}^{*}=1.1797 \mathrm{x}-0.0778$ & 75.90 & 0.40 & 1.50 \\
\hline PBZ (SAC) & 5 & $\hat{y}^{* *}=-16.405 x^{2}+6.0938 x+0.2501$ & 65.15 & 0.19 & 0.81 \\
\hline SAC (PBZ) & 0 & $\hat{\mathrm{V}}^{* *}=0.0543 \mathrm{x}-0.0488$ & 66.17 & 20.00 & 0.92 \\
\hline SAC (PBZ) & 0.1 & $\hat{y}^{* *}=-0.0068 x^{2}+0.1977 x+0.0637$ & 87.38 & 14.54 & 1.50 \\
\hline
\end{tabular}

** and $*$ significant at $1 \%$ and $5 \%$ of probability, respectively, by the $\mathrm{F}$ test of ANOVA.

pyramidalis) under minimal growth conditions, found values for coefficient of determination between $77.00 \%$ and $99.00 \%$. These higher values reflect the better fit of the equations generated by the study, thus demonstrating the reliability of the generated data.

In absence of SUC and $0.06 \mathrm{mg} \mathrm{L}^{-1}$ of PBZ, the lowest plant heights $(1.35 \mathrm{~cm})$ were found (Table 2). This reduction is possibly related to PBZ presence, which acts by inhibiting gibberellin synthesis (Seesangboon et al., 2018), hormone responsible for cell elongation (Martínez et al., 2018). Therefore, the action mode of PBZ has been associated with decreased plant height and leaf area (Panyapruek et al., 2016). Vettorazzi et al. (2017), on the other hand, found in studies of in vitro conservation of sweet potato (Ipomoea batatas), that reduced plant growth was possible when in absence of sucrose, having lower rates of leaf production.

However, based on the premise that plant height should be associated with other variables, the dose of $0.1 \mathrm{mg} \mathrm{L}^{-1}$ PBZ combined with $5 \mathrm{~g} \mathrm{~L}^{-1}$ SUC demonstrated good results, considering one of the lowest estimated means for plant height $(11.33 \mathrm{~cm})$ and the lowest mean for number of senescent leaves (0.8) (Table 2). These results diverge from those obtained by Silva et al. (2016) who, working on in vitro conservation of blackberries trees (Rubus sp.), found that the dose of $45 \mathrm{~g} \mathrm{~L}^{-1}$ SUC reduced the multiplication rate, as well as the results found by Rezende et al. (2018), who achieved short-term in vitro conservation of Physalis peruviana by using a dose of $30 \mathrm{~g} \mathrm{~L}^{-1} \mathrm{SUC}$.
Additionally, the combination of these two abovementioned concentrations of PBZ and SUC are associated with higher means for the numbers of mini-cuttings (7.82), roots (4.21), shoots (1.34) and green leaves (8.47), thus revealing the expressive effect of this interaction on the in vitro conservation of $M$. pseudoglaziovii. This is interesting for conservation because, despite the reduction in plant height, the other variables should present the best values for maintaining the varieties from plants conserved in vitro. Still on the shoot, Cardoso et al. (2018) reported that the highest means in leaf production for the cassava variety (BRS Verdinha) was obtained with the concentration of $30 \mathrm{~g} \mathrm{~L}^{-1}$ SUC. Furthermore, these same authors report that this increase may be associated with the source-drain relation, considering that the greater the SUC accumulation in leaves is, the greater the transfer to the roots and the development of tubers will also be.

Experiment II: Effect from different concentrations of paclobutrazol (PBZ) and sucrose (SUC) on in vitro conservation of the species $M$. violaced

Summary of the analysis of variance (Table 3 ) demonstrates that the interaction PBZ $\times$ SUC was also significant for all variables.

It is also noted an oscillation from $4.56 \%$ (NB) to $28.93 \%$ (NSL) in the coefficients of variation (CV). Table 4 illustrates the polynomial regression models, where the coefficients of determination $\left(R^{2}\right)$ varying from 51.18 to $100 \%$ for number of senescent leaves and plant height are observed, respectively.

Table 3. Summary of the analysis of variance for plant height (PH, in $\mathrm{cm}$ ), number of mini-cuttings (NM), number of roots (NR), number of shoots (NS), number of green leaves (NGL) and number of senescent leaves (NSL) of the species M. violácea, as a function of concentrations of paclobutrazol (PBZ) and sucrose (SUC).

\begin{tabular}{|c|c|c|c|c|c|c|c|}
\hline \multirow{2}{*}{ VF } & \multirow{2}{*}{ DoF } & \multicolumn{6}{|c|}{ MS } \\
\hline & & PH & NME & NR & NS & NGL & NSL \\
\hline PBZ & 4 & $97.03^{* *}$ & $3.70^{* * *}$ & $1.49^{* * *}$ & $0.03^{\text {ns }}$ & $1.10^{* *}$ & $1.67^{*+4}$ \\
\hline SUC & 3 & $731.77^{* *}$ & $17.05^{* *}$ & $20.50^{* *}$ & $0.06^{n s}$ & $1.18^{* *}$ & $7.20^{* *}$ \\
\hline PBZ $\times$ SUC & 12 & $31.82^{* *}$ & $0.76^{* *}$ & $0.468^{* *}$ & $0.06^{* *}$ & $0.76^{* *}$ & $0.71^{*}$ \\
\hline Error & 232 & 7.46 & 0.14 & 0.22 & 0.02 & 0.27 & 0.32 \\
\hline \multicolumn{2}{|c|}{ CV (\%) } & 25,92 & 13.14 & 30.41 & 4.56 & 22.79 & 28.93 \\
\hline \multicolumn{2}{|c|}{ Overall Mean } & 10,54 & 7.82 & 2.41 & 1.03 & 4.94 & 3.72 \\
\hline
\end{tabular}

ns $=$ non-significant; ${ }^{* *}$ and ${ }^{*}$ significant at 1 and $5 \%$, respectively, by the $\mathrm{F}$ test. 
Table 4. Regression equations, coefficients of determination, optimum dose and estimated values of plant height (cm), number of mini-cuttings, number of sprouts, number of green leaves and number of senescent leaves of the species $M$. violacea, as a function of concentrations of paclobutrazol (PBZ) and sucrose (SUC).

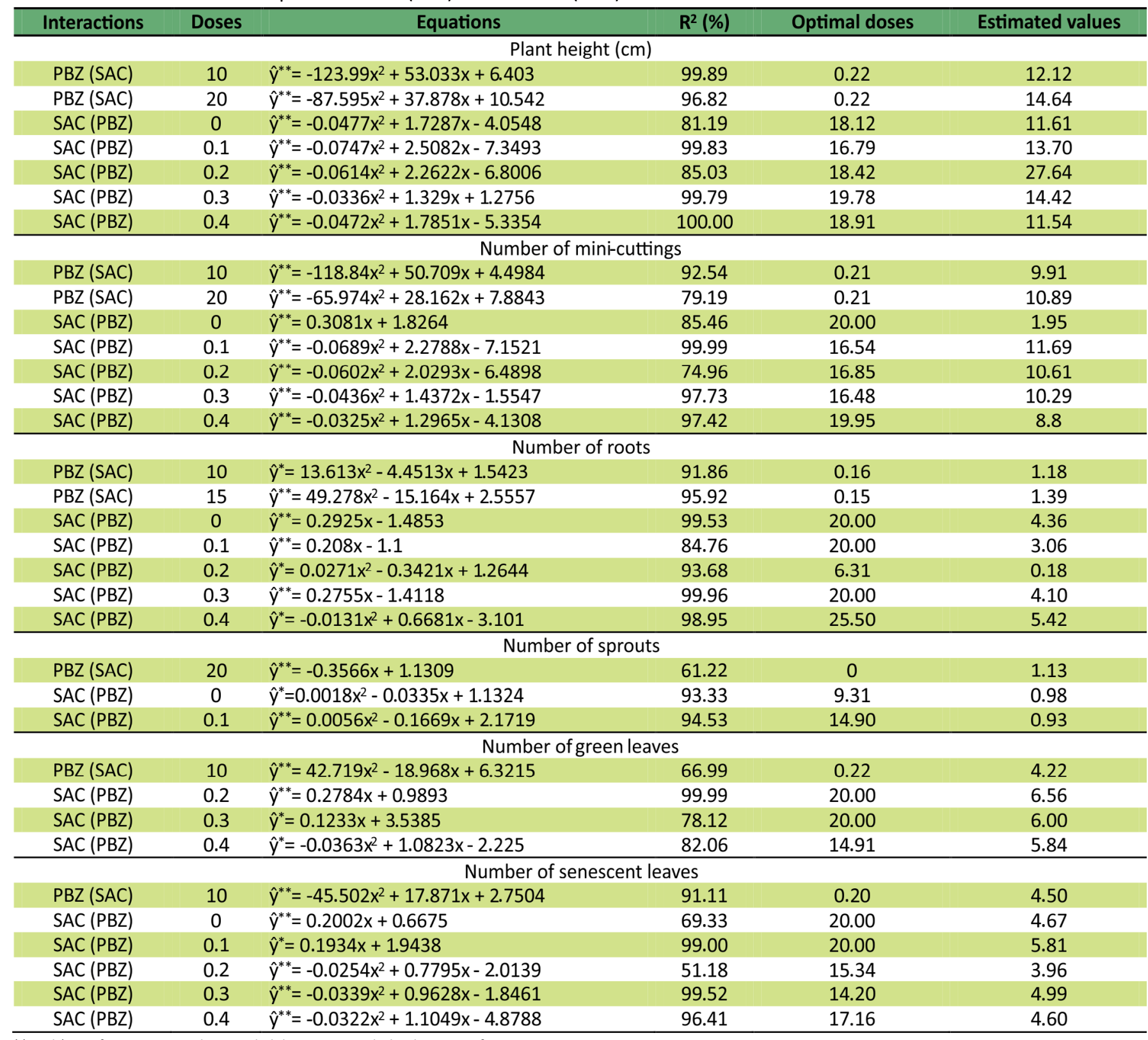

** and * significant at $1 \%$ and $5 \%$ probability, respectively, by the $\mathrm{F}$ test of ANOVA.

In this experiment, the highest estimated mean for number of roots (5.42) occurred in the association of $0.4 \mathrm{mg} \mathrm{L}^{-1}$ of PBZ and $25.50 \mathrm{~g} \mathrm{~L}^{-1}$ of SUC (Table 4). The development of the root system during the conservation period is important for later acclimatization of plants, since transferring them to the field is a necessity. Negi et al. (2017) reported the action mode of PBZ has been associated with root thickening and thus the plant probably has more adaptive mechanisms for a future ex vitro condition.

As for the variable number of shoots, the dose of $20 \mathrm{~g}$ $\mathrm{L}^{-1} \mathrm{SUC}$, in absence of PBZ, had the highest estimated mean (1.13). However, Ramírez-Mosqueda et al. (2019) found that absence of PBZ on conservation of the Laelia anceps orchid was not efficient for preserving plants under low growth-rate conditions.
The interaction between concentrations of $10 \mathrm{~g} \mathrm{~L}^{-1} \mathrm{SUC}$ and $0.2 \mathrm{mg} \mathrm{L}^{-1} \mathrm{PBZ}$ influenced both the number of green leaves (4.22) and the number of senescent leaves (4.50), besides presenting a positive behavior regarding plant height $(12.12 \mathrm{~cm})$ and number of mini-cuttings (9.91), thus revealing the superiority of this treatment for Manihot violacea. This same SUC dose was the one found by Cardoso et al. (2018) as the responsible for providing the best vegetative development for the BRS Verdinha cassava variety. Agreeing to the stated, Figueiredo et al. (2018) observed that SUC doses lower than $30 \mathrm{~g} \mathrm{~L}^{-1}$ are sufficient to maintain the plant survival rates, although decreased growth occurred in conservation of jenipapo tree (Genipa americana). 
Experiment III: Effect from different concentrations of paclobutrazol (PBZ) and sucrose (SUC) on in vitro conservation of the M. flabelifolia genotype

Table 5 illustrates the summary of the analysis of variance, where the interaction PBZ x SUC was significant for number of roots, number of green leaves and number of senescent leaves.

In relation to the plant height, number of mini-cuttings and shoots, the isolated SUC factor had significant effect. There was a variation from $9.07 \%$ (NS) to $48.49 \%(\mathrm{PH})$ in CV. Table 6 illustrates the polynomial regression models, in which we can observe the fitting of first and second degree models, with the coefficient of determination $\left(R^{2}\right)$ ranging from $52.80 \%$ for number of senescent leaves to $100 \%$ for number of green leaves and number of senescent leaves.

When analyzing the variables of plant height, number of mini-cuttings and number of shoots it was not possible to fit a significant model for the concentrations of SUC and PBZ.
As with the mean values of the other variables evaluated in this experiment, the metabolism reduction was decisive for the unviability of this species, making it necessary to conduct further studies involving other culture media and concentrations of PBZ and SUC. Faria et al. (2006), although able to fit regression models on in vitro conservation of passion-fruit vines (Passiflora giberti), also concluded that applying SUC to the culture medium is not necessary.

In contrast, Vieira et al. (2015) were able to fit an optimal SUC concentration that enabled the in vitro viability of Manihot esculenta plants. Hence, as reported by Souza et al. (2020), for each species there may be different responses when sucrose is added to the culture medium. It is also interesting to mention that, depending on the used concentration, sucrose may hinder formation and growth of the roots and shoots.

Several studies in the literature are found aiming to maintain minimum growth rates for in vitro conservation of germplasm. Among these is the research developed

Table 5. Summary of the analysis of variance for plant height $(\mathrm{PH}, \mathrm{in} \mathrm{cm})$, number of mini-cuttings (NM), number of roots (NR), number of shoots (NS), number of green leaves (NGL) and number of senescent leaves (NSL) of the M. flabelifolia genotype, as a function of concentrations of paclobutrazol (PBZ) and sucrose (SUC).

\begin{tabular}{|c|c|c|c|c|c|c|c|}
\hline \multirow{2}{*}{ VF } & \multirow{2}{*}{ DoF } & \multicolumn{6}{|c|}{ MS } \\
\hline & & $\mathrm{PH}$ & NM & NR & NS & NGL & NSL \\
\hline PBZ & 4 & $0.43^{n s}$ & $0.16^{*}$ & $0.04^{* * *}$ & $0.04^{*}$ & $1.10^{* *}$ & $0.32^{\text {ns }}$ \\
\hline SUC & 3 & $2.98^{*}$ & $0.23^{*}$ & $0.02^{n s}$ & $0.04^{*}$ & $0.33^{\text {ns }}$ & $0.16^{\mathrm{ns}}$ \\
\hline PBZ $\times$ SUC & 11 & $0.40^{\text {ns }}$ & $0.07^{n s}$ & $0.05^{* *}$ & $0.02^{n s}$ & $0.33^{*}$ & $0.33^{*}$ \\
\hline Error & 137 & 0.65 & 0.07 & 0.01 & 0.01 & 0.15 & 0.14 \\
\hline \multicolumn{2}{|c|}{ CV (\%) } & 48.49 & 19.46 & 14.85 & 9.07 & 19.18 & 38.57 \\
\hline \multicolumn{2}{|c|}{ Overall Mean } & 1.66 & 1.39 & 0.04 & 1.12 & 1.66 & 0.60 \\
\hline
\end{tabular}

ns $=$ non-significant; ${ }^{* *}$ and ${ }^{*}$ significant at 1 and $5 \%$, respectively, by the $\mathrm{F}$ test.

Table 6. Regression equations, coefficients of determination, optimum doses and estimated values of plant height (cm), number of mini-cuttings, number of sprouts, number of green leaves and number of senescent leaves of the Manihot flabelifolia genotype, as a function of concentrations of paclobutrazol (PBZ) and sucrose (SUC).

\begin{tabular}{|c|c|c|c|c|c|}
\hline Interactions & Doses & Equations & $\mathbf{R}^{2}(\%)$ & Optimal doses & Estimated values \\
\hline \multicolumn{6}{|c|}{ Plant height $(\mathrm{cm})$} \\
\hline SAC & & $\hat{\mathrm{y}}^{\mathrm{ns}}=1.64$ & - & & $1.64^{1}$ \\
\hline \multicolumn{6}{|c|}{ Number of mini-cuttings } \\
\hline SAC & & $\hat{y}^{n s}=1.35$ & - & & $1.35^{1}$ \\
\hline \multicolumn{6}{|c|}{ Number of roots } \\
\hline PBZ (SAC) & 15 & $\hat{y}^{*}=3.5714 x^{2}-1.9286 x+0.2214$ & 85.71 & 0.27 & 0.4 \\
\hline PBZ (SAC) & 20 & $\hat{y}^{* *}=17.857 x^{2}-11.071 x+1.6071$ & 93.33 & 0.31 & 0.11 \\
\hline$S A C(P B Z)$ & 0 & $\hat{\mathrm{y}}^{* *}=0.025 \mathrm{x}-0.1667$ & 75.00 & 20 & 0.33 \\
\hline SAC (PBZ) & 0.0001 & $\hat{y}^{* *}=0.0071 x^{2}-0.1357 x+0.5357$ & 93.33 & 9.56 & 0.11 \\
\hline \multicolumn{6}{|c|}{ Number of sprouts } \\
\hline PBZ & & $\hat{y}^{n s}=1.14$ & - & & $1.14^{1}$ \\
\hline SAC & & $\hat{y}^{n s}=1.10$ & - & & $1.10^{1}$ \\
\hline \multicolumn{6}{|c|}{ Number of green leaves } \\
\hline PBZ (SAC) & 10 & $\hat{y}^{* *}=-8.125 x+6.0143$ & 81.52 & 0.4 & 6.01 \\
\hline PBZ (SAC) & 20 & $\hat{y}^{* *}=-71.29 \times 2+33.733 x+0.4756$ & 99.96 & 0.24 & 4.47 \\
\hline SAC (PBZ) & 0 & $\hat{y}^{* *}=-0.0658 x^{2}+1.0958 x+2$ & 100.00 & 8.33 & 6.56 \\
\hline SAC (PBZ) & 0.1 & $\hat{y}^{* *}=-0.0329 x^{2}+0.8186 x-0.1786$ & 94.00 & 12.44 & 4.91 \\
\hline \multicolumn{6}{|c|}{ Number of senescent leaves } \\
\hline PBZ (SAC) & 15 & $\hat{y}^{* *}=12.464 x 2-7.5588 x+1.3293$ & 52.80 & 0.3 & 0.18 \\
\hline PBZ (SAC) & 20 & $\hat{y}^{* *}=40.417 x^{2}-24.658 x+4.0625$ & 100.00 & 0.31 & 0.30 \\
\hline SAC (PBZ) & 0 & $\hat{y}^{* *}=0.1292 x-0.4306$ & 90.89 & 20 & 2.15 \\
\hline SAC (PBZ) & 0.1 & $\hat{y}^{* *}=0.0246 x^{2}-0.5537 x+3.1286$ & 87.76 & 11.25 & 0.13 \\
\hline
\end{tabular}

** and ${ }^{*}$ significant at $1 \%$ and $5 \%$ probability, respectively, by the $\mathrm{F}$ test of ANOVA; ${ }^{1}$ based on the mean of observed. 
by Wu et al. (2019), who, working with lilies (Lilium sp.), obtained positive responses regarding the retardation of plant material development. Silva et al. (2019) also reported satisfactory results on in vitro conservation of "catingueira" (Poincianella pyramidalis), recommending using culture media supplemented with SUC and PBZ for up to 240 days, without subculture.

Due to the importance of maintaining and conserving genetic resources, the need for studies directed to preservation of wild Manihot species is evident, since there are no reports of research of this nature in the literature. Moreover, in face of the divergent results, the morphogenic response is expressively influenced by the species, demonstrating the need for further studies aiming at a better adequacy of the protocols for each species.

\section{Conclusions}

For the species $M$. pseudog/aziovii, the interaction of 0.1 $\mathrm{mg} \mathrm{L}^{-1}$ paclobutrazol and $5 \mathrm{~g} \mathrm{~L}^{-1}$ sucrose promoted a significant effect on its in vitro conservation. While for the species $M$. violacea, the concentration of $10 \mathrm{~g} \mathrm{~L}^{-1}$ sucrose and $0.2 \mathrm{mg} \mathrm{L}^{-1}$ PBZ is the most indicated for its conservation. Lastly, for $M$. flabelifolia, the used concentrations of SUC and PBZ were not efficient for its in vitro conservation.

\section{Compliance with Ethical Standards}

Author contributions: Conceptualization: AAA, CASL, MJSC; Data curation: DMSS; Formal analysis: DMSS, CASS, MJSC; Funding acquisition: ASS, CASL; Investigation: JFS, DMSS, KCFS; Methodology: DMSS, ASS, CASL, MJSC; Project administration: DMSS; Resources: KCFS, ASS; Software: CASL, MJSC; Supervision: ASS, CASL, MJSC; Validation: JFS; Visualization: JFS, DMSS, KCFC; Writing - original draft: JFS, DMSS, KCFS; Writing - review \& editing; ASS, CASL, MJSC.

Conflict of Interest: The authors declare no conflict of interest.

Funding: We thank the Coordenação de Aperfeiçoamento Pessoal de Nível Superior (CAPES) for the financial assistance to the scholarship. To Embrapa Cassava and Tropical Fruits, for providing all infrastructure and financial support to conduct the study.

\section{Literature Cited}

Arrigoni-Blank, M. de F; Tavares, F. F.; Blank, A. F.; Santos, M. C. dos; Menezes, T. S. A.; Santana, A. D. D. de. In vitro conservation of sweet potato genotypes. Scientific World Journal, v. 2014, e208506, 2014. https://doi.org/10.1155/2014/208506.

Cardoso, M. N.; Araujo, A. G. de; Silva, A. V. C. da; Oliveira, L. A. R. de; Lédo, A. da S. Influência de luz e sacarose no crescimento in vitro de mandioca. Nucleus, v. 15, n. 1, p. 85-93, 2018. https:// doi.org/10.3738/1982.2278.2710.
Faria, G. A; Costa, M. A. P. de C.; Junghans, T. G.; Ledo, C. A. S.; Souza, A. S. Efeito da sacarose e sorbitol na conservação in vitro de Passiflora giberti N. E. Brown. Revista Brasileira de Fruticultura, v. 28 , n. 2, p. 267-270, 2006. https://doi.org/10.1590/S010029452006000200025.

Ferreira, D. F. Sisvar: a computer statistical analysis system. Ciência e Agrotecnologia, v. 35, n. 6, p. 1039-1042, 2013. https://doi. org/10.1590/S1413-70542011000600001.

Figueiredo, J. R. M; Paiva, P. D. de O.; Paiva, R.; Silva, D. P. C. da; Mesquita, R.; Faria, C. V. N. de; Reis, M. V. dos. Conservação de Genipa americana: Técnicas de encapsulamento e crescimento lento. Revista da Universidade Vale do Rio Verde, v. 16, n. 1, p. 1-9, 2018. https://doi.org/10.5892/ruvrd.v16i1.4931.

Grattapaglia, D.; Machado, M. A. Micropropagação. In: Torres, A. C.; Caldas, L. S.; Buso, J. A. (Eds.). Cultura de tecidos e transformação genética de plantas. Brasília: Embrapa-SPI; Embrapa-CNPH, 1998. p. 183-260.

International Centre for Tropical Agriculture - CIAT. El cultivo de meristemas para La conservación de germoplasma de yuca in vitro, unidad audiotutorial. Cali: CIAT, 1984. 44. (CIAT. Guía de Estudio. Serie 045C- 05.03).

Marco-Medina, A.; Casas, J. L. Polyamine content during minimal growth storage of Thymus moroderi explants. Biologia Plantarum, v. 56, n. 3, p. 590-594, 2012. https://doi.org/10.1007/s10535012-0061-y.

Martínez,C.;Espinosa-Ruiz,A.;Prat,S.Gibberellinsand plantvegetative growth. In: Hedden, P.; Thomas, S.G. (Eds.). Annual Plant Reviews, Volume 49: The Gibberellins. Chichester: Wiley Blackwell, 2018. p.285-322. https://doi.org/10.1002/9781119210436.ch10.

Negi, S. S.; Lal, S.; Sah, H. Influence of growth retardant on vegetative growth and leaf chlorophyll content of jackfruit (Artocarpus heterophyllus). International Journal of Pure and Applied Bioscience, v. 5, n. 1, p. 142-146, 2017. https://doi. org/10.18782/2320-7051.2466.

Panyapruek, S. N.; Sinsiri, W.; Sinsiri, N.; Arimatsu, P.; Polthanee, A. Effect of paclobutrazol growth regulator on tuber production and starch quality of cassava (Manihot esculenta Crantz). Asian Journal of Plant Sciences, v. 15, n. 1/2, p. 1-7, 2016. https://doi. org/10.3923/ajps.2016.1.7.

Ramírez-Mosqueda, M. A.; Cruz-Cruz, C. A.; Atlahua-Temoxtle, J.; Bello-Bello, J. J. In vitro conservation and regeneration of Laelia anceps Lindl. South African Journal of Botany, v. 121, p. 219-223, 2019. https://doi.org/10.1016/j.sajb.2018.11.010.

Rezende, R. A. L. S; Pasqual, M.; Carvalho, S. P.; Pereira, A. R.; Villa, F. $V$. In vitro conservation of Cape gooseberry through slow-growth nodal segment cultures. Pesquisa Agropecuária Brasileira, v. 53, n. 5, p. 651-655, 2018. https://doi.org/10.1590/s0100$204 \times 2018000500015$.

Roca, W. M.; Arias, D. I.; Chavéz, R. Métodos de conservación in vitro del germoplasma. In: Roca, W. M.; Mroginski, L. A. (Eds.). Cultivo de tejidos en la agricultura: fundamentos y aplicaciones. Cali: CIAT, 1991. p. 697-713.

Seesangboon, A.; Gruneck, L.; Pokawattana, T.; Eungwanichayapant, P. D.; Tovaranonte, J.; Popluechai, S. Transcriptome analysis of Jatropha curcas L. flower buds responded to the paclobutrazol treatment. Plant Physiology and Biochemistry, v. 127, p. 276-286, 2018. https://doi.org/10.1016/j.plaphy.2018.03.035 
Silva, C. M. M. de S.; Fay, E. F.; Vieira, R. F. Degradação do paclobutrazol em solos tropicais. Pesquisa Agropecuária Brasileira, v. 38, n. 10 , p. 1223-1227, 2003. https://doi.org/10.1590/s0100204X2003001000012.

Silva, N. D. G. da; Dutra, L. F.; Bianch, V. J.; Sommer, L. R.; Vargas, D. P.; Peters, J. A. Conservação in vitro de amoreira-preta: Crescimento lento. Plant Cell Culture \& Micropropagation, v. 12, n. 1, p. 7-12, 2016. https://ainfo.cnptia.embrapa.br/digital/bitstream/ item/147278/1/Leonardo-Plant-Cell-Numero-1-2016-2.pdf. 19. Aug. 2020.

Silva, T. S.; Nepomuceno, C. F.; Soares, T. L.; Santana, J. R. F. In vitro conservation of Poincianella pyramidalis (Tul.) L.P. Queiroz under minimal growth conditions. Ciência e Agrotecnologia, v. 43, e014519, 2019. https://doi.org/10.1590/14137054201943014519.

Souza, L. M.; Barbosa, M. R.; Souza, R. A.; Bussmeyer, E. C.; Houllou, L. $M$. Influence of sucrose on growth and profile of photosynthetics pigments in two arboreal species cultivated in vitro. Brazilian Journal of Development, v. 6, n. 1, p. 1916-1626, 2020. https:// doi.org/10.34117/bjdv6n1-135.
Vettorazzi, R. G.; Carvalho, V. S.; Sudré, C. P.; Rodrigues, R. Developing na in vitro optimized protocol to sweet potato landraces conservation. Acta Scientiarum. Agronomy, v. 39, n. 3, p. 359367, 2017. https://doi.org/10.4025/actasciagron.v39i3.32700.

Vieira, L. J.; Santana, J. R. F.; Vidal, A. M.; Alves, A. A. C.; Souza, A. S.; LEDO, C. A. S.; Souza, F. V. D. Use of multivariate analysis to evaluate the effect of sucrose on in vitro cassava conservation. African Journal of Biotechnology, v. 14, n. 5, p. 419-424, 2015. https:// doi.org/10.5897/AJB2014.14210.

Werner, E. T.; Motta, L. B.; Martins, M. Q.; Lima, A. B. P.; Schmildt, E. R. Coeficiente de variação como medida da precisão em experimentos de cultura de tecidos de plantas. Plant Cell Culture \& Micropropagation, v. 8, n. 1-2, p. 27-36, 2012. https://doi. org/10.18227/1982-8470ragro.v11i4.4412.

Wu, Y.; Sun, M.; Zhang, J.; Zhang, L.; Ren, Z.; Min, R.; Wang, X.; Xia, $Y$. Differential effects of paclobutrazol on the bulblet growth of oriental lily cultured in vitro: growth behavior, carbohydrate metabolism, and antioxidant capacity. Journal of Plant Growth Regulation, v. 38, n. 2, p. 359-372, 2019. https://doi.org/10.1007/ s00344-018-9844-5. 